\title{
Influence of infection of soybean seeds with Peronospora manshurica and Pseudomonas syringae pv. glycinea on protein, oil and fatty acids content
}

\section{J. MARCINKOWSKA ${ }^{1}$, M. SCHOLLENBERGER ${ }^{1}$, L. BOROS ${ }^{2}$}

${ }^{1}$ Department of Phytopathology, Warsaw Agricultural University, Nowoursynowska 166, 02-766 Warszawa, Poland

${ }^{2}$ Soybean Laboratory, Institute of Plant Breeding and Acclimatization, 05-870 Radzików, Poland

$\langle$ Received: May 17, 1983〉

\begin{abstract}
The effect of soybean seed infection by Peronospora manshurica and Pseudomonas syringae pv. glycinea on the chemical content of some soybean lines and varieties susceptible to both pathogens was estimated. The amount of protein and oil was determined for soybean seed samples collected from two different localities in 1980. In P. manshurica oospore-encrusted seeds protein content was higher and oil content lower than in healthy ones. It could be seen especially in samples of the 'Acme' variety cultivated in both localities. Seed infection by $P$. syringae pv. glycinea occasionally influenced the protein, oil and fatty acid content as compared with the control. This was noted only in single cases. Analysis of fatty acid composition demonstrated a higher free fatty acid content in soybean seed infected by $P$. manshurica. These results showed undoubtedly the influence of pathogens, specially seed-borne fungi on the chemical soybean seed composition. This analysis can be an introduction for more detailed investigations on the effect of these or other pathogens on soybean seed yield quality.
\end{abstract}

\section{INTRODUCTION}

C o r s o and Porto $\langle 1978\rangle$ demonstrated a fall of the oil level in soybean seeds infected with unidentified fungi.

In Poland Pseudomonas syringae pv. glycinea 〈Coerper〉 Young, Dye and Wilkie and Peronospora manshurica 〈Naum $\rangle$ Syd. et Gaum. appear usually with an epidemic intensity, therefore, it is difficult to find in the field plants completely free of these pathogens. It is impossible to estimate the losses caused by these pathogens under conditions of natural infection, therefore, an attempt was undertaken to determine the influence of these pathogens on the quality of the soybean seed crop. The protein, oil and fatty acids contents in seeds of some chosen soybean varieties were determined. 


\section{MATERIAL AND METHODS}

Seeds of soybean Glycine max $\langle$ L. $>$ Merr. were used from the 1980 harvest in the Soybean Laboratory, Institute of Plant Breeding and Acclimatization, Radzików, Warsaw District and from the experimental station Jankowice of the Experimental Department of Plant Breeding and Acclimatization in Ożańsk, Przemyśl District.

For analysis seeds were taken of varieties and lines susceptible to $P$. manshurica and Pseudomonas syringae pv. glycinea. The sensitivity of the varieties was evaluated under field conditions in the period of highest incidence of the diseases. Varieties inflected in degree $3\langle$ medium $\rangle$ to $4\langle$ high $\rangle$, in the $0-5$ score, were chosen to the study $\langle\mathrm{M}$ a r c i n k o w s k a et al., 1982 $\rangle$. Degree 3 means small not very numerous spots on leaves of all the plants or numerous merging larger spots, beginning of necroses on a about 50 per cent of the plants; degree 4 represents numerous merging spots of various sizes, frequent necroses, small leaves destroyed in about 75 per cent of plants. The following varieties and lines were taken into account in the investigations: 'Acme', 'Portage' and $\mathrm{K} 3 / 2$, NM 4961 susceptible to $P$. manshurica, and 'Aretic', 'Progres' $\langle$ IHAR 78/B $\rangle$ and NM 4855 susceptible to $P$. syringae pv. glycinea. For determination of fatty acids plants from only one locality were taken, where a higher incidence of the given pathogen was observed. In the case of the fungus $P$. manshurica, seeds from Jankowice were analysed, and for the bacterium $P$. syringae pv. glycinea seeds from Radzików were studied.

Seed samples were taken from $1.5 \mathrm{~kg}$ lots of the particular varieties and lines. From among the seeds of varieties susceptible to $P$. manshurica, those were selected under a binocular $\langle\times 25\rangle$ which were covered with oospores of this fungus, referred to further as infected and seeds with a clean surface free of other fungi, termed healthy.

Protein and oil contents were determined in four samples of 30 seeds of each variety or line from both localities.

From the lot of varieties susceptible to $P$. syringae pv. glycinea eight samples of 50 seeds for each variety were taken. One half of these samples were soaked for $4 \mathrm{~h}$ in $100 \mathrm{ml}$ of sterilised water at $4^{\circ} \mathrm{C}$. Repeated shaking washed the bacteria off the seed surface. Four $0.1 \mathrm{ml}$ suspension samples were taken and each of them was inoculated on plates with King B medium for counting the number of bacterial cells present in the suspension. The soaked samples were treated as control in reference to the seeds from which bacteria were not washed off, referred to as infected.

Protein and oil contents were determined in samples of 30 seeds ground in a mill. Analyses were performed in two replications with the use of the infralyzer 〈Technicon, USA〉 apparatus. The apparatus was graduated according to standard samples in which protein was determined by the Kjeldahl method and 
oil in the Foss-let apparatus 〈Foss - electric, Denmark〉 with extraction by means of tetrachloroethylene. The correlation between classical methods and the Infralyzer was for protein 0.98 and for oil 0.96 .

The particular fatty acids content in the soybean oil was determined by gas chromatography $\langle\dot{Z}$ ó r a w s k i and K u p r y s z e w s k i, 1971 $\rangle$. Seeds of the particular varieties ground with sand previously washed with concentrated hydrochloric acid were placed in glass columns and infused with ethyl ether. Ampoules were placed under the columns for collecting the oil extract. The ether was evaporated and the oil was saponified. To each of the $6 \mathrm{mg}$ oil samples $1 \mathrm{ml}$ of $0.5 \mathrm{~N}$ potassium hydroxide solution in methanol was added.

The ampoules were then heated for $3 \mathrm{~min}$ to boil. After cooling $2 \mathrm{ml}$ of 1 per cent thionyl chloride solution in methanol was added and the ampoules were once more heated for $3 \mathrm{~min}$ to boil. Then the ampoule necks were drawn in a gas burner to an about $1 \mathrm{~mm}$ diametre and about $5 \mathrm{ml}$ of saturated aqueous solution of sodium chloride was added to each. From thus prepared samples $0.2 \mathrm{ml}$ of extract were injected into a gas chromatograph 〈PYE - 104〉.

All results were subjected to 2 or 3 factorial analysis of variance.

\section{RESULTS}

On the varieties 'Acme' and 'Portage' and the lines K 3/2 and NM-4961 mean or even strong infection with $P$. manshurica in Radzików and Jankowice was observed $\langle$ Table 1$\rangle$. The same varieties proved also susceptible to $P$. syringae $\mathrm{pv}$. glycinea. Infection of these varieties and lines by the bacterium was low in Jankowice but in Radzików both the pathogens caused a similar intensity of

\section{Table 1}

Infection of some soybean varieties and lines in field conditions, 1980 , disease rate $0-5$

\begin{tabular}{|c|c|c|c|c|}
\hline \multirow{3}{*}{$\begin{array}{c}\text { Cultivar } \\
\text { Strain }\end{array}$} & \multicolumn{4}{|c|}{ Mean degree of plant infection } \\
\hline & \multicolumn{2}{|c|}{$\begin{array}{r}\text { Peronospora } \\
\text { manshurica }\end{array}$} & \multicolumn{2}{|c|}{$\begin{array}{c}\text { Pseudomonas syringae } \\
\text { pv。glycinea }\end{array}$} \\
\hline & Radzików & Jankowice & Radzików & Jankowice \\
\hline 'Acme' & 3.75 & 3.25 & 3.00 & 1.50 \\
\hline Portage' & 3.25 & 3.50 & 2.75 & 1.50 \\
\hline K $3 / 2$ & 2.75 & 3.00 & 1.75 & $\mathbf{1}_{0} 40$ \\
\hline NM-4961 & 2.75 & 3.00 & $\mathbf{3 . 0 0}$ & 1.50 \\
\hline 'Aretic' & 0.25 & 0.25 & 4.00 & 3.25 \\
\hline 'Progres' & 0 & 0 & 3.00 & 2.50 \\
\hline NM-4855 & 1.25 & 1.00 & 3.25 & 2.75 \\
\hline
\end{tabular}


infection. 'Aretic', 'Progres' and NM-4855 were moderately and strongly infected by $P$. syringae pv. glycinea and little sensitive to $P$. manshurica.

Comparison of the protein content in healthy and infected by $P$. manshurica seeds of various soybean varieties cultivated in Radzików and Jankowice showed only a difference for the variety 'Acme' $\langle$ Table 2$\rangle$. On the other hand, seeds of the variety 'Portage' cultivated only in Radzików and of the line K 3/2 in Jankowice contained a different percentage of protein. In Jankowice the protein per cent in soybean seeds of various varieties was higher than in Radzików. Significant

Table 2

Mean percentual content of protein in healthy soybean seeds and those infected by Peronospora manshurica

\begin{tabular}{|c|c|c|c|c|}
\hline \multirow{3}{*}{$\begin{array}{r}\text { Cultivar } \\
\text { Strain }\end{array}$} & \multicolumn{4}{|c|}{ Seeds from } \\
\hline & \multicolumn{2}{|c|}{ Radzików } & \multicolumn{2}{|c|}{ Jankowice } \\
\hline & healthy & infected & healthy & infected \\
\hline 'Acme' & 38.6 & 40.6 & 40.9 & 42.9 \\
\hline 'Portage' & 37.8 & 39.7 & 41.5 & 42.2 \\
\hline $\mathrm{K} 3 / 2$ & $34_{b} 1$ & 34.1 & 40.7 & 42.5 \\
\hline NM-4961 & 37.8 & 37.3 & 42.1 & 42.5 \\
\hline $\mathrm{LSD}, \mathrm{p}=0.05$ & \multicolumn{4}{|c|}{0.9} \\
\hline $\begin{array}{l}\text { Means for localities } \\
\text { LSD, } p=0.05\end{array}$ & \multicolumn{2}{|c|}{37.5} & \multicolumn{2}{|c|}{41.9} \\
\hline
\end{tabular}

Table 3

Mean percentual content of oil in healthy soybean seeds and those infected by

Peronospora manshurica

s

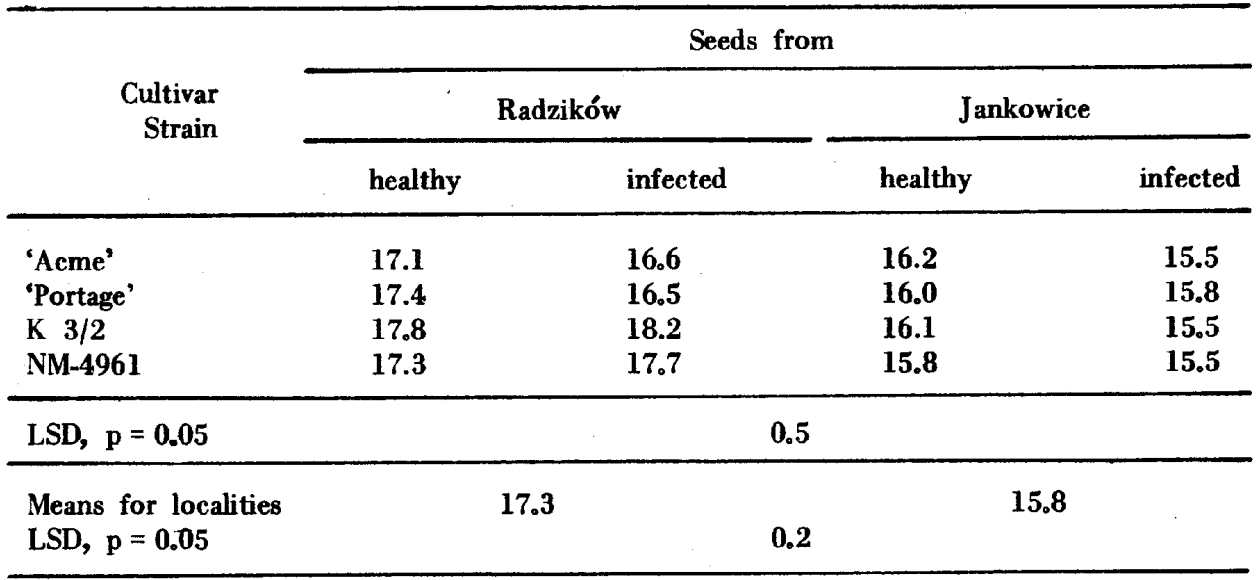


differences in protein content in most varieties were found without of regard to the health condition of the seeds and locality of cultivation 〈Table 2〉.

The fungus $P$. manshurica depressed the oil content in seeds of the variety 'Acme' harvested in Radzików and Jankowice 〈Table 3〉. Infected seeds of the variety 'Portage' grown in Radzików had a lower oil content. A similar influence was observed on the seeds of the line K $3 / 2$ in Jankowice. Considerable differences in oil content in seeds of all soybean varieties and lines were observed in dependence on the locality where they were cultivated $\langle$ Table 3$\rangle$.

In healthy soybean seeds the protein content was lower than in those infected with $P$. manshurica, and in the case of lipids, the healthy seeds showed a higher content than those infected by this fungus $\langle$ Table 4$\rangle$.

Table 4

Effect of Peronospora manshurica infection on protein and oil contents in soybean seeds

\begin{tabular}{lcc}
\hline & \multicolumn{2}{c}{ Percentual contents } \\
\cline { 2 - 3 } & protein & oil \\
\hline Healthy & 39.2 & 16.7 \\
Infected & 40.2 & 16.4 \\
\hline LSD, $p=0.05$ & 0.3 & 0.2 \\
\hline
\end{tabular}

Washing off of $P$. syringae pv. glycinea bacteria from soybean seeds increased the protein content in seeds of the variety 'Aretic' grown in Jankowice $\langle$ Table 5 $\rangle$. This relation was not noted in the remaining combinations, but differences were found in protein content between the localities and varieties 〈Table 5〉.

Table 5

Mean percentual content of protein in control soybean seeds and those infected by Pseudomonas syringae pv. glycinea

\begin{tabular}{|c|c|c|c|c|}
\hline \multirow{3}{*}{ Cultivar } & \multicolumn{4}{|c|}{ Seeds from } \\
\hline & \multicolumn{2}{|c|}{ Radzików } & \multicolumn{2}{|c|}{ Jankowice } \\
\hline & control & infected & control & infected \\
\hline $\begin{array}{l}\text { 'Aretic'- } \\
\text { 'Progres' }\end{array}$ & $\begin{array}{l}35.9 \\
36.5\end{array}$ & $\begin{array}{l}35.2 \\
35.8\end{array}$ & $\begin{array}{l}41.9 \\
39.3\end{array}$ & $\begin{array}{l}42.4 \\
39.8\end{array}$ \\
\hline LSD, $p=0.05$ & & & & \\
\hline $\begin{array}{l}\text { Means for localities } \\
\text { LSD, } p=0.05\end{array}$ & & & & \\
\hline
\end{tabular}


In soaked seed of the 'Progres' variety from the Radzików crop the lipids content was lower than in those considered as infected by $P$. syringae pv. glycinea $\langle$ Table 6$\rangle$. No such relation was observed in the variety 'Aretic'.

Differences were noted in percentual oil content in seeds of plants cultivated in Radzików and Jankowice, without of regard to treatment and variety $\langle$ Table 6〉.

\author{
Table 6
}

Mean percentual content of oil in control soybean seeds and those infected by Pseudomonas syringae pv. glycinea

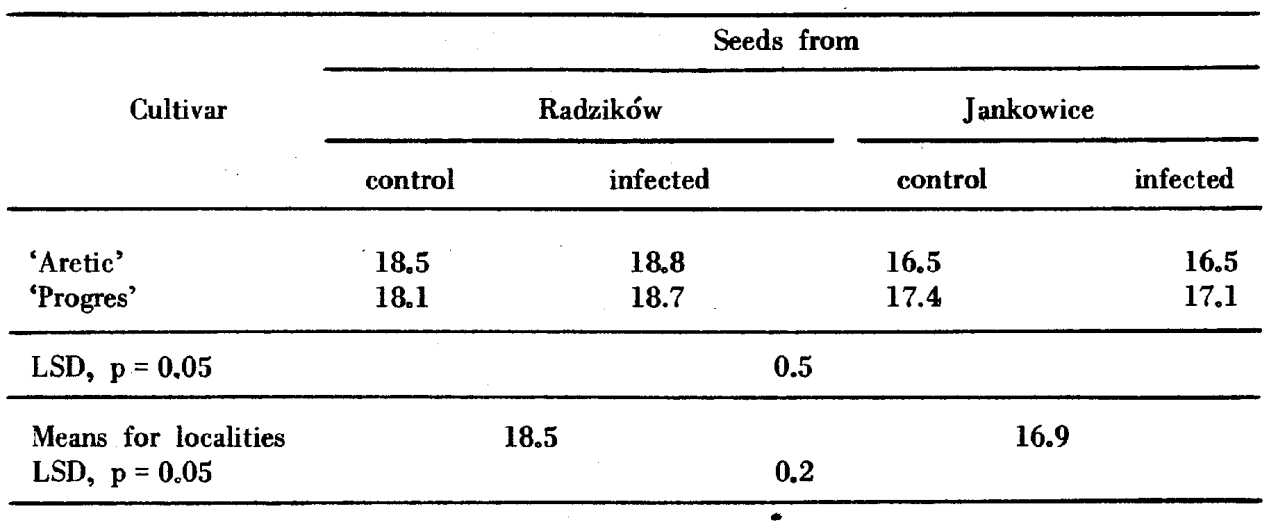

The bacterial population on soaked seeds from Radzików was several times larger than on seeds from Jankowice and this caused a reduction of the protein content and a higher lipids amount $\langle$ Tables 5,6〉.

Washing off of bacteria did not change the percentage of protein in seeds of the varieties 'Aretic' and 'Progres' derived both from Radzików and Jankowice and did not affect the oil content $\langle$ Table 7$\rangle$.

$$
\text { Table } 7
$$

Effect of Pseudomonas syringae pv. glycinae infection on protein and oil contents in soybean seeds

\begin{tabular}{lcc}
\hline \multirow{2}{*}{ Seeds } & \multicolumn{2}{c}{ Percentual contents } \\
\cline { 2 - 3 } & protein & oil \\
\hline & & \\
Control & 38.4 & 17.6 \\
Infected & 38.3 & 17.8 \\
\hline $\mathrm{LSD}, \mathrm{p}=0.05$ & 0.5 & 0.2 \\
\hline
\end{tabular}




\section{Table 8}

Mean percentual of fatty acid content in healthy soybean seeds and those infected by Peronospora manshurica

\begin{tabular}{|c|c|c|c|c|c|c|c|c|c|c|}
\hline \multirow{2}{*}{$\begin{array}{c}\text { Cultivar } \\
\text { Strain }\end{array}$} & \multicolumn{2}{|c|}{ Linolenic acid } & \multicolumn{2}{|c|}{ Linolic acid } & \multicolumn{2}{|c|}{ Oleic acid } & \multicolumn{2}{|c|}{ Stearic acid } & \multicolumn{2}{|c|}{ Palmitic acid } \\
\hline & healthy & infected & healthy & infected & healthy & infected & healthy & infected & healthy & infected \\
\hline 'Acme' & 13.8 & 15.8 & 53.4 & 53.9 & 19.7 & 17.7 & 2.6 & 2.8 & 10.5 & 10.2 \\
\hline 'Portage' & 13.6 & 14.5 & 55.9 & 56.6 & 18.4 & 16.9 & 2.7 & 2.4 & 9.5 & 9.7 \\
\hline $\mathrm{K} 3 / 2$ & 13.8 & 16.9 & 53.4 & 56.7 & 19.6 & 15.2 & 2.9 & 1.9 & 10.2 & 9.3 \\
\hline NM-4961 & 14.3 & 15.4 & 58.2 & 58.6 & 15.1 & 14.0 & 2.8 & 2.6 & 9.7 & 9.4 \\
\hline $\mathrm{LSD}, p=0.05$ & & 1.6 & 2.3 & 2.3 & & 3.2 & & 0.6 & & 0.9 \\
\hline $\begin{array}{l}\text { Means for } \\
\text { combinations }\end{array}$ & 13.9 & 15.6 & 55.3 & 56.4 & 18.2 & 15.9 & 2.7 & 2.4 & 10.0 & 9.7 \\
\hline LSD, $p=0.05$ & & 0.8 & & 1.2 & & 1.6 & & 0.3 & & 0.4 \\
\hline
\end{tabular}


Ta ble 9

Mean percentual of fatty acid content in control soybean seeds and those infected by Pseudomonas syringae pv. glycinea

\begin{tabular}{|c|c|c|c|c|c|c|c|c|c|c|}
\hline \multirow{2}{*}{$\begin{array}{l}\text { Cultivar } \\
\text { Strain }\end{array}$} & \multicolumn{2}{|c|}{ Linolenic acid } & \multicolumn{2}{|c|}{ Linolic acid } & \multicolumn{2}{|c|}{ Oleic acid } & \multicolumn{2}{|c|}{ Stearic acid } & \multicolumn{2}{|c|}{ Palmitic acid } \\
\hline & control & infected & control & infected & control & infected & control & infected & control & infected \\
\hline 'Aretic' & 13.6 & 13.2 & 59.4 & 58.3 & 14.9 & 16.5 & 2.4 & 2.3 & 9.7 & 9.7 \\
\hline 'Progres' & 14.2 & 13.6 & 59.2 & 57.8 & 13.5 & 15,4 & 26 & 2.7 & 10.4 & 10.4 \\
\hline NM-4855 & 13.3 & 12.5 & 57.7 & 55.6 & 16.1 & 18.4 & 2.7 & 3.0 & 10.1 & 10.5 \\
\hline $\mathrm{LSD}, \mathrm{p}=0.05$ & \multicolumn{2}{|c|}{1.4} & \multicolumn{2}{|c|}{1.8} & \multicolumn{2}{|c|}{2.1} & \multicolumn{2}{|c|}{0.7} & \multicolumn{2}{|c|}{0.7} \\
\hline $\begin{array}{l}\text { Means for } \\
\text { combinations }\end{array}$ & 13.7 & 13.1 & 58.8 & 57.2 & 14.9 & 16.8 & 2.6 & 2.7 & 10.1 & 10.2 \\
\hline LSD, $p=0.05$ & \multicolumn{2}{|c|}{0.8} & \multicolumn{2}{|c|}{1.1} & \multicolumn{2}{|c|}{1.2} & \multicolumn{2}{|c|}{0.4} & \multicolumn{2}{|c|}{0.4} \\
\hline
\end{tabular}


In determination of fatty acids in healthy seeds and infected ones with $P$. manshurica the percentual content of the following acids: linolenic, linolic, oleic and stearic was different $\langle$ Table 8$\rangle$. This was noted when the total amount of fatty acids was compared in seeds of all the tested varieties. When the successive soybean varieties were considered, this dependence was confirmed only in the case of the line K $3 / 2$. In seeds of plants of the 'Acme' variety a difference was only found in linolenic acid content.

In seeds infected with $P$. manshurica the content of unsaturated fatty acids, that was linolenic and linolic acids was higher.

A difference was found in soaked soybean seeds in the content of linolic and oleic acids as compared with that in seeds infected with $P$. syringae pv. glycinea, when the varietal differences were not taken into account $\langle$ Table 9$\rangle$. Statistically significant difference in the percentual content of these two acids were found in seeds from the line NM-4855.

\section{DISCUSSION}

The presented results give preliminary information on the influence of pathogens on the chemical composition of soybean cultivated in Poland.

As seen from the reported data, it is difficult to determine the influence of only one of the two studied pathogens because the majority of the crop varieties and lines under test are susceptible, sometimes to various degrees, to the pathogens prevailing in this country. It seems that some pathogens, especially fungi, may influence the quality of the seed crop.

Accurate studies on the influence of pathogens on the seed quality should be performed separately on seeds of healthy and of infected plants.

It is difficult, however, in the case of Pseudomonas syringae pv. glycinea and Peronospora manshurica, pathogens commonly appearing on soybean under natural conditions, to find plants free from these pathogenic factors. In order to obtain the necessary number of healthy plants, chemical protection is necessary. However, the influence of the fungicides on the chemical composition of the seeds would have to be tested, since fungicide application is not without effect on the plants.

$\mathrm{P}$ e $\mathrm{n} \mathrm{n}$ e $\mathrm{r}$ and $\mathrm{M}$ e g g i t $\langle 1970\rangle$ observed small differences in the fatty acids composition in soybean seeds treated with 13 herbicides, whereas J o h n s o n and J e l l u m <1969> using only four herbicides found no differences.

In view of this situation it was decided to determine the influence of the pathogens present on the seeds on their chemical composition. In the choice of the varieties from which seed samples were taken, their susceptibility under field conditions to the given pathogen was taken into account. All varieties and lines of soybean grown in Poland are, however, infected with $P$. syringae pv. glycinea, so 
that varieties considered in the study as sensitive to $P$. manshurica were also infected with the latter bacterium. Infection of the varieties was estimated in the field on the basis of the degree of destruction of the leaf blade, this being known to be correlated with soybean seed infection $\langle\mathrm{B}$ o $1 \mathrm{k}$ a $\mathrm{n}$ and $\mathrm{C} \mathrm{u} \mathrm{p} \mathrm{e} \mathrm{r} \mathrm{t} \mathrm{i} \mathrm{no}$, 1976; E 11 i s et al., 1976 .

C o r s o and P o r t o $\langle 1978\rangle$ when investigating the influence of some unidentified fungi on protein and lipids content in soybean seeds of the 'Davis' variety observed a decrease of oil content in the infected seeds. The same dependence was found also for soybean infected with $P$. manshurica, but it was not observed in seeds infected with $P$. syringae pv. glycinea.

In the present results differences in protein content were noted in soybean seeds under the influence of $P$. manshurica. The higher protein content in seeds overgrown with mycelium and oospores of $P$. manshurica is probably due to the additional protein source in the pathogen organism developing from the substances of the growing plant.

It has also been reported by $\mathrm{H}$ a $\mathrm{r} \mathrm{t}\langle 1970\rangle, \mathrm{T}$ o d d s and $\mathrm{T} \mathrm{u} \mathrm{r}$ n i p s e d $\langle 1974\rangle$ and C or s o and P o r t o $\langle 1978\rangle$ that in soybean seed damaged by Homoptera the protein content is enhanced.

It is necessary to have available plant material with extreme differences in susceptibility for determining the influence of bacteria on the chemical composition of seeds. H a r t w i g and $\mathrm{J}$ o h n s o $\mathrm{n}\langle 1953\rangle$ having soybean seeds of resistant and susceptible lines to $X$ anthomonas phaseoli var. sojensis were able to establish significant differences in protein and oil content.

Analysis of the fatty acids composition in soybean seeds infected with $P$. manshurica revealed a higher content of unsaturated fatty acids in them. Similar results were obtained by $\mathrm{H}$ a r $\mathrm{t}\langle 1970\rangle$ in studies on soybean seeds damaged by Homoptera.

\section{REFERENCES}

B o $1 \mathrm{k}$ a n H. A., C u p e r $\mathrm{t}$ i n o F. P., 1976. Effect of foliar applications of fungicides on the control of seed-borne Phomopsis and yield of soybean. Fitopatologia Brasileira 1: 215-218.

C or s o I. C., P o r t o M. D. M., 1978. Relacao entre o efeito associate de percevejos e fungos na producao e teores de oleo e proteina de sementes de soja. Agron. sulriograndense, Porto Alegre 14, 1: 41-46.

E 11 i s M.A., F o o r S. R., S i n c 1 a i r J. B., 1976. Effect of benomyl sprays on internally-borne fungi and germination of delay-harvested soybean seeds. Phytopath. Z. 85; 159-162.

H a $\mathrm{r}$ t J. R., 1970. Methods for determining the extent of stinkbug damage in soybeans. III. Relation of stink bug damage to quality in soybeans. Cereal Chemistry $47 ; 545-548$.

Har twig E. E., Joh n s o n H. W., 1953. Effect of the bacterial pustule disease on yield chemical composition of soybeans. Agron. J. 45: 22-23. 〈Cyt. wg Rev. Appl. Mycol. 32, 416, 1953>.

J o h n s o n B. J., J e 11 u m M. D., 1969. Effect of pesticides on chemical composition of soybean seed. Agron. J. 61: 379-380. 
Marcink ow ska J., Tom a la-Bednarek J., Scholle n be rge r M., 1982. Soybean diseases in Poland. Acta Agrobot. 35: 213-224.

P e $n$ n e $r$ D., M e g g i t W. F., 1970. Herbicide effects on soybean seed lipids. Crop Science 10: 553-555.

T o d d J., T u r n i p s e e d S. G., 1974. Effects of southern green stink bug damage on yield and quality of soybeans. J. Econ. Entomology 67: 421-426.

Żó r a w s k i A., K u p r y s z e w s k i G., 1971. Zastosowanie chlorku tionylu w reakcji otrzymywania estrów metylowych kwasów thuszczowych używanych do oznaczeń ilościowych metodą GLC. Tłuszcze Jadalne. 15: 136-139.

\section{Wpływ porażenia nasion soi przez Peronospora manshurica i Pseudomonas syringae pv. glycinea na zawartość białka, tłuszczu i kwasów tłuszczowych}

\section{Streszczenie}

Do oceny wpływu porażenia nasion soi przez $P$. manshurica i $P$. syringae pv. glycinea na ich skład chemiczny wybrano kilka odmian soi najbardziej podatnych na poszczególne patogeny, w warunkach polowych. Zawartość białka i thuszczu badana była w nasionach soi zebranych w Radzikowie 〈woj. warszawskie〉 i w Jankowicach 〈woj. przemyskie〉, w 1980 r.

W badanych nasionach odmian wrażliwych na $P$. manshurica obserwowano wyższą zawartość białka a niższą tłuszczu w porównaniu do nasion zdrowych. Dotyczyło to zwłaszcza próbek nasion odmiany 'Acme' pochodzących $z$ obu miejscowości. Porażenie nasion przez bakterię P. syringae pv. glycinea nie powodowało zmian zawartości białka, tłuszczu i kwasów tłuszczowych w odniesieniu do nasion kontrolnych. Zjawisko to potwierdzało się w pojedynczych kombinacjach. W porażonych próbkach nasion odmiany 'Aretic' z Jankowic stwierdzono wyższą zawartość białka. Porażone nasiona odmiany 'Progres' z Radzikowa cechowały się wyższym procentem tłuszczu. Analiza składu kwasów tluszczowych wykazała wyższą zawartość nienasyconych kwasów tłuszczowych w nasionach soi porażonych przez $P$. manshurica.

Przedstawione badania wskazują na niewątpliwy wpływ patogenów, zwłaszcza grzybów przenoszonych z nasionami, na skład chemiczny nasion soi. 